\title{
Den galiziska mångfaldens tragedi: professorsmorden i krigstidens Lviv och åminnelsen av dem
}

\author{
Eleonora Narvselius*
}

Lunds universitet, Sverige

\begin{abstract}
A tragedy of the Galician diversity: Murder and commemoration of Polish professors killed in Lviv during WWII

In popular imagery, the former Habsburg province of Galicia and its capital city Lemberg/ Lwów/Lviv have been acclaimed for their unique mixture of religions, cultures and nationalities. However, there are also darker sides of this Galician diversity, as became evident during the wars and crises of the first half of the twentieth century. It is instructive to explore how the entanglements between collective and individual choices, cultural genealogies and political aspirations looked in practice in this part of Europe, and how historical events of the twentieth century have reflected this complexity. This article explores one such event: the murder of a group of eminent Polish academics during the Nazi occupation of Lviv/Lwów. After the war, this tragic episode was commemorated quite independently in the two parts of Galicia now divided by the redrawn Polish-(Soviet)Ukrainian border. The episode remains controversial due to the contradictory interpretative frameworks and agenda-setting of various actors involved into the memorialization. The author draws on Michael Rothberg's concept of multidirectional memory to highlight how reverberations of Galician diversity can be approached from an anthropological perspective, focusing on meaning-making and agency.
\end{abstract}

Keywords: Galicia, WWII, diversity, commemoration, OUN, multidirectional memory, Polish professors

Som ett mångkulturellt gränsområde är Galizien knappast unikt i Europa. Det har påpekats att

Austrian Galicia was not unique in terms of its cultural diversity. Other European regions such as Alsace, Bohemia, and Silesia were equally diverse, and the Vojvodina, Transylvania, and Macedonia were even more so. In all of these places, the interaction between varying peoples and cultures produced rivalry and competition that had both a positive as well as negative impact on the political, economic, and in particular, cultural status of each group. (Magocsi, 2005, s. 10)

\footnotetext{
^Kontaktinformasjon: Eleonora Narvselius, epost: Eleonora.Narvselius@slav.lu.se 


\section{4 | ELEONORA NARVSELIUS}

Det som dock är intressant ur kulturantropologisk synpunkt är inte bara att flera nationaliteter länge samexisterade i regionen till dess att den historiska mångfalden utplånades i mitten av tjugonde århundradet. Ännu mer angeläget är att utforska hur det komplicerade samspelet mellan språkliga och kulturella val, ideologiska orienteringar och politiska strävanden såg ut i praktiken, exakt hur olika historiska företeelser återspeglade denna komplexitet, samt vilka konsekvenser motstridiga tolkningar av ödesdigra historiska händelser kunde ha för efterföljande minneskulturer. Denna antropologiska fallstudie som bygger på fältarbete, arkivmaterial samt sekundära källor kommer att sätta komplicerade turer omkring en sådan händelse och dess åminnelse i fokus. Syftet är att demonstrera hur motsägelsefulla tolkningar, rykten och ageranden sattes igång i samband med mord och åminnelse av en grupp polska akademiker som avrättades i en nazistockuperad galizisk metropol samt hur de återaktualiserade skiljelinjer och rivaliteter med rötter i lokala samlevnadsmönster. Michael Rothbergs teoretisering av "mångdimensionellt minne» (multidirectional memory) tas till vara för att utöka kunskapsläget om den historiska galiziska mångfaldens efterskalv.

\section{Den galiziska mångfalden: en balansgång mellan samspel och nollsummespel}

Lviv, en stad som är också känd som Leopolis, Lemberg, Lwów och Lvov beroende på epok och den härskande elitens etnokulturella tillhörighet, är idag ett attraktivt turistmål som ger en glimt av glansen från tiden som huvudstad i den habsburgska provinsen Galizien samt en kulturmetropol i mellankrigstidens Polen. Nutida berättelser om Lviv/Lwów som förmedlas i populärkulturella, politiska, men även akademiska sammanhang, understryker stadens och provinsens unika blandning av religioner, kulturer och nationaliteter. Denna mångkultur hyllas ofta och framställs då som en samling pusselbitar i "den galiziska mosaiken», eller som enskilda historier med anknytning till olika nationaliteter - polsk, ukrainsk, judisk, armenisk, österrikisk med flera. Tillsammans har detta bidragit till att skapa en idyllisk bild av Galicia Felix, en galizisk mångfald som har presenterats i form av parallella berättelser om individuella folkslag, som trots sina skiljaktigheter under många århundraden levde i fredlig samvaro och har skapat en unik regional kultur. ${ }^{1}$ I detta sammanhang kan man dock fråga sig hur mycket av den bild av mångkultur som förmedlas reflekterar de verkliga förhållandena i det habsburgska riket, och i vilken mån det rör sig om en idealiserad rekonstruktion.

En annan aspekt som förtjänar en fördjupning är vilka kulturella hierarkier och vanor som utvecklades i den ganska stabila kontexten av habsburgskt fin de siècle fortsatte att gälla även under ändrade politiska omständigheter. Under det tjugonde

\footnotetext{
${ }^{1}$ Ett exempel på sådana berättelser var den välrecenserade utställningen Mytos Galizien, som visades i Wien och Kraków under år 2015.
} 
seklet genomlevde Galizien tre krig (första världskriget, den kortvariga polskukrainska konflikten om Galizien strax därefter och andra världskriget) samt flera ödesdigra händelser som radikalt förändrade regionens demografiska struktur. Som en följd av detta förpassades galizisk mångfald i dess habsburgska variant till det förflutna, medan nationell enfald i stället blev en norm. Därför är det är viktigt att veta hur relationer mellan etniska grannar - som alltid haft sina mörka sidor då förräderi och omoraliska allianser satte sin prägel både på stora politiska spel och på det personliga planet - utvecklades efterhand.

I sådana mångkulturella gränsområden som Galizien har skiljelinjer mellan olika kategorier och identiteter varit suddigare, mer förhandlingsbara och "porösa" än i mer centrala regioner (Bialasiewicz, 2003; Czaplicka, 2002; Hann \& Magocsi, 2005; Wolff, 2010; Bartov \& Weitz, 2013; Linkiewicz, 2018; Narvselius, 2019). Detta ledde till framväxten av olika hybrididentiteter, till exempel de så kallade latynnyky, det vill säga ukrainskspråkiga romerska katoliker, men öppnade också möjligheter för individer att göra självständiga kulturella val. Som bevis på denna betydande valfrihet, framför allt i städerna, kan man peka på statistik över konversioner (Wnęk, Zyblikiewicz \& Callahan, 2006, s. 93-108), men också på många släkthistorier, av vilka den kanske mest kända handlar om den aristokratiska släkten Fredro-Szeptycki. Både den klassiske polske författaren Alexander Fredro, den patriotiske polske generalen Stanisław Szeptycki och Andrij Sjeptytskyj, den grekisk-katolske metropoliten och spirituelle ledaren för den ukrainska befolkningsgruppen i Galizien, härstammade från samma familj. Emellertid begränsades sådan flexibilitet av en hel del bestämmelser som till exempel dem som avgjorde vilken konfession som barn i blandade familjer skulle tillhöra. Även om assimilering av judisk befolkning i det polska språket och högkulturen tog fart mot slutet av den habsburgska perioden, var samtidigt giftermål med icke-judar fortfarande sällsynta. ${ }^{2}$ Vad som på ytan kunde se ut som strikt individuella val var i själva verket resultaten av spel enligt både skrivna och oskrivna regler, där det tillåtna mättes mot det praktiska, det tänkbara mot det önskvärda och så vidare.

Tydliga sprickor i detta välutvecklade, men ömtåliga kulturella underlag uppstod redan i början av 1900-talet (Hann, 2005, s. 221). Som framgår av en studie om angiveri och karaktärsmord i mellankrigstidens Galizien ${ }^{3}$ har brutalisering av mellanmänskliga relationer i sviten av första världskriget och den polska segern $i$ kriget över Galizien 1918-1919 satt igång diskursiva mekanismer av etniskt nollsummespel. Fruktansvärda effekter av ryktesspridning, förtal och angiveri riktade mot "de andra» $i$ ens närhet blev fullt synliga under sovjetisk och tysk ockupation under andra världskriget (Wendland, 2005). Även under efterkrigsperioden fortsatte

\footnotetext{
${ }^{2}$ Dessa stod bara för runt $1 \%$ av alla mellankonfessionella äktenskap i regionen (Spickard, 1989, s. 167).

${ }^{3}$ Som sedan övertagandet av den återuppstådda polska staten började kallas MalpolskaWschodnia, det vill säga östra Lillpolen.
} 
dock liknande diskursiva strategier av misstänkliggörandet av sina före detta grannar att sättas i spel på båda sidor av den politiska gräns som nu delade Galizien mellan Polen och det sovjetiska Ukraina (se Zashkilniak, 2008; Wnuk, 2013; Khakhula, 2016; Szabłowski, 2016), även om den officiella retoriken fortsatte att upprepa klichéer om internationalism och broderliga relationer.

Ett användbart teoretiskt ramverk som fokuserar på hur kollektiva föreställningar, retoriska argument och representationer kopplade till det tragiska förflutna fortsätter att verka under olika skepnader i nutida kontexter är Michael Rothbergs multidirectional memory. Rothberg poängterar att olika minnen och kulturella narrativ till synes kan försvinna från offentligheten för att omvandlas och fortsätta verka i annorlunda - ibland överraskande - former. Minnen om tragiska händelser inte bara manipuleras, glöms eller tystas, utan förflyttas också av diverse sociala, psykologiska och politiska krafter till olika kontexter. Där samspelar de med andra kulturella representationer som hände inte bara samtidigt med de ihågkomna episoderna utan även före och efter dem (Rothberg, 2009, s. 13-16). I det som följer kommer jag att koppla detta teoretiska resonemang till en diskussion om efterdyningar av galizisk mångfald.

\section{Den historiska kontexten av mordet på Wuleckie kullar: komplicerade samspel, tilltrasslade historier}

I „täta» miljöer som genomsyras av så många komplicerade konstellationer och maktspel mellan individer, folkgrupper och institutioner är historiska företeelser oftast svåröverskådliga och mångdimensionerade. Konflikterna tenderar att bli långdragna och svåra att avsluta just på grund av denna "tilltrasslade» samvaro, där respons och agerande kommer från olika håll och inte alltid i en förutsägbar form. Möjligheten till kompromiss och en enad front till stöd för gemensamma intressen är ofta försvinnande liten på grund av olika särintressen samt talrika minnen av tidigare ömsesidiga orättvisor. De krig, radikala och snabba regimombyten, politiska utrotningsaktioner, fördrivningar och exproprieringar som det tjugonde seklet frambringade gjorde att grupper och individer kunde bli såväl varandras offer som förövare. Just denna katastrofala utveckling ser vi i Galizien i samband med de båda världskrigen och deras extrema våld och brutalitet (se vidare Barkan, Cole \& Struve, 2007; Mick, 2015; Liber, 2016).

Ett komplext händelseförlopp i Lvivs historia, omkring vilket många frågor, rykten och spekulationer uppstod, är det massvåld som utlöstes i början av den nazistiska ockupationen av staden. För en historieskrivning med ett strikt nationellt perspektiv, som inte tar hänsyn till en lokal verklighet av både samexistens, ojämlika villkor och rivalitet mellan etnokulturella miljöer, politiska grupper och individuella lojaliteter, blir dessa episoder närmast obegripliga. Särskilt belysande i detta avseende är den tragiska händelse som utspelade sig 3 till 4 juli 1941, nämligen mordet på en grupp polska akademiker samt efterkrigstidens försök att hedra deras minne, 
något som dock motarbetades eller ifrågasattes från flera håll. Berättelsen om hur denna händelse blev "tilltrasslad» i den lokala kontexten, och hur dess ambivalens och obesvarade frågor bidrog till senare problem kring högtidlighållandet av minnet av professorsmordet, är i sig en mycket komplicerad historia. Låt oss dock börja med en kort redogörelse för vad som föregick denna tragedi i Lviv.

I september 1939 blev Polen attackerat och delat mellan Tyskland och Sovjetunionen i enlighet med det hemliga tilläggsprotokollet till Molotov-Ribbentroppakten. Efter den polska kapitulationen 23 september 1939 införlivades Lviv med sovjetrepubliken Ukraina. Enligt pakten fick omkring 60000 galiziska tyskar lämna sovjetannekterade områden (Müller, 2012), samtidigt som den nya regimen genast påbörjade en rensning av Lviv och östra Galizien från "fientliga element». Enligt 1931 års folkräkning bestod stadens befolkning av 50,44\% polacker, $31,9 \%$ judar, $15,61 \%$ ukrainare och ungefär $2 \%$ andra grupper (Makarchuk, 2007, s. 447), men efter 1939 förändrades denna bild radikalt. Under den korta första perioden av sovjetiskt styre i början av andra världskriget (september 1939-juni 1941) fängslades och deporterades hundratusentals människor av olika nationaliteter, dock med en tydlig överrepresentation av etniska polacker. ${ }^{4} \mathrm{De}$ »första sovjeterna» föreföll att privilegiera den etniskt ukrainska befolkningen, medan polackerna, som i den sovjetiska diskursen stämplades som "överherrar» och "utsugare», tvangs anpassa sig till att deras etniska rivaler upphöjdes.

Nämnas bör att inkorporeringen av östra Galizien i Polen efter det korta, men intensiva polsk-ukrainska kriget 1918-1919 följdes av en period då högre utbildning $i$ regionen karakteriserades av allvarliga konflikter. De polska myndigheterna antingen ignorerade eller till och med uppmuntrade diskriminering och förföljelse av judiska studenter, vilket resulterade i dödliga tumult inom universitetsområdena. Dessutom bröt polackerna löftet om att ett särskilt ukrainskt universitet skulle inrättas i Lviv. ${ }^{5}$ Patriotiska ukrainska ungdomar som önskade högre utbildning valde att fortsätta sina studier utomlands (Zavorotna, 2020). En av de mest kända - men också ökända - ledarna för den ukrainsk-nationalistiska organisationen OUN ${ }^{6}$, Stepan Bandera, tilläts dock inte studera i tjeckiska Poděbrady år 1927. Han kom senare till Lwóws

\footnotetext{
${ }^{4}$ Enligt beräkningar som gjorts av den polske historikern Grzegorz Hryciuk (nämnda i Makarchuk, 2007, s. 447) minskade under den korta perioden av sovjetiskt styre den polska befolkningen med 110000 personer $(7,5 \%)$ i hela östra Galizien, av vilka 20000 försvann från Lviv. Förluster bland den ukrainska befolkningen utgjorde under samma tid 50000 personer $(1,7 \%)$ och bland judarna 15000 personer $(8,5 \%)$.

${ }^{5}$ Mer om detta i: Redzik, 2017, s. 157-97.

${ }^{6}$ Organisationen för ukrainska nationalister (OUN) var en radikal politisk rörelse som kämpade för inrättande av en oberoende stat i Ukraina. Den utövade revolutionär terrorism och riktade sina attacker främst mot polacker och sovjeter. Efter splittringen 1940 blev dess två falanger kända som OUN(b), banderivtsi, och OUN(m), mel'nykivtsi, efter deras respektive ledare Stepan Bandera och Andrij Mel'nyk. OUN:s roll förblir ifrågasatt i efterkrigstidens historieskrivning, särskilt när det gäller samarbete med Nazityskland, deltagande i utrotningen av judar och massmorden på polacker i Volynien och Galizien 1943-1944. Se mer i Partyliak, 2004; Motyka, 2015.
} 
polytekniska universitet där han under flera år läste agronomi. En annan politisk aktivist som tillhörde topparna inom OUN:s hierarki och som läste vid samma lärosäte var Roman Sjukhevytj.

Efter sovjetstyrets införande i Lviv och östra Galizien förbättrades ukrainarnas situation, liksom judarnas, $i$ åtminstone ett viktigt avseende: de nya regler som gällde vid antagning till universitet resulterade i en väsentlig ökning av antalet studenter från de båda befolkningsgrupperna. Vad gäller universitetspersonal föredrog sovjeterna att åtminstone under den första tiden behålla de flesta specialister som stannade kvar i Lviv. Även om Lwówakademin inte hade några Nobelpristagare i sina led, åtnjöt den hög internationell prestige tack vare sin medicinska forskning (Rudolf Weigl m.fl.), sin ryktbara matematikermiljö (bl.a. Hugo Steinhaus och Stefan Banach) och sin berömda filosofiska Lwów-Warzsawska-skola (med bl.a. Kazimierz Twardowski och Jan Łukasiewicz). I början av sovjetperioden bestod cirka $40 \%$ av den akademiska personalen av etniska polacker, men på professorsnivå var polacker i klar majoritet (52 personer), jämfört med ukrainare (22) och judar (8). Vid de polytekniska, medicinska och veterinära instituten ${ }^{7}$ var de flesta professorerna polacker (Hryciuk, 2000, s. 130). Inom den lokala akademin replikerades alltså förkrigstidens etnisk-kulturella hierarkier, vilket betydde att gamla antagonismer fortsatte att glöda under ytan även under de förändrade politiska omständigheterna.

De konflikter som underblåstes under två år av sovjetiskt styre i början av andra världskriget utlöste en våg av brutalitet och repressioner vid bytet av politisk regim. Antijudiskt våld utbröt efter upptäckten av tiotusentals dödade fångar som sovjeterna lämnade efter sig i flera västukrainska städer. ${ }^{8}$ När lokalbefolkningen öppnade fängelserna efter Röda arméns reträtt kom den makabra åsynen av högar av kroppar som en chock även för dem som vid den tiden var väl medvetna om den sovjetiska säkerhetstjänstens brutalitet. Desperation och hämndlystnad kopplades snabbt till myten om judisk bolsjevism och manipulerades skickligt av nazisterna, de nya härskare som inom kort inträdde i Lviv. Antijudiskt gatuvåld, som krävde över 4000 liv, inleddes strax före tyskarnas ankomst och fortsatte i flera veckor (Mick, 2016, s. 289-95).

Det första militära förband som marscherade in i staden 29 juni 1941 var Nachtigall-bataljonen, som bestod av tyskarnas ukrainska allierade, anhängare till Banderas falang av OUN. Ukrainska nationalister hyste förhoppningar om en suverän ukrainsk stat under tyskt protektorat, och Nachtigall-bataljonens närvaro i Lviv var för dem av yttersta strategiska vikt. Förbandet övertog bland annat stadens radiostation, från vilken OUN utropade ukrainsk självständighet 30 juni 1941. Även om

\footnotetext{
${ }^{7}$ Under "första sovjeterna» omvandlades Lwóws politekiniska universitet, veterinärakademin samt den medicinska fakulteten av Jan Kazimierz-universitetet till institut.

${ }^{8}$ Antalet fångar som mördades vid reträten uppskattas till mellan 20000 och 40 000. Bland dem var två tredjedelar ukrainare, en femtedel polacker och resten människor av olika nationaliteter, så som judar, tjeckar, tyskar, belarusier och ryssar (Kiebuzinski \& Motyl, 2017, s. 40).
} 
organisationens ideologi i flera avseenden upprepade nazistiska doktriner och framställde Hitlers Tyskland som sin främsta förebild, var dess huvudsyfte och agenda av en annan karaktär. OUN:s ideologiska bas kan bäst beskrivas som integral-nationalism, en ultrakonservativ världsåskådning med starka inslag av främlingsfientlighet, dock utan direkta rasdoktriner, som framställde den suveräna ukrainska staten som sitt främsta mål (Zaitsev, 2013; Shkandrij, 2015). Under de kritiska första dagarna av regimskiftet var Nachtigall-bataljonens medlemmar engagerade $i$ att utropa den ukrainska staten. Samtidigt finns det bevis på att ukrainare i tyskarnas tiänst deltog i den pogrom som utbröt i Lviv efter upptäckten av NKVD:s offer, bland vilka man också hittade Jurii Sjukhevytj, en bror till Nachtigall-bataljonens befälhavare Roman Sjukhevytj (Himka, 2011, s. 226).

Nachtigall-bataljonens kontroversiella historia blev kort. I och med att de högsta tyska ledarna blev varse att OUN hade utropat en ukrainsk stat utan deras tillstånd fick bataljonen order att lämna Lviv 7 juni. I augusti upplöstes förbandet, och en del av dess styrka skickades till Vitryssland där den sattes in i aktioner mot partisaner och lokal befolkning (Rudling, 2019). I början av 1943 avväpnades denna grupp och dess officerare arresterades. Roman Sjukhevytj lyckades dock fly och ansluta sig till den ukrainska upprorsarmén (UPA). Som dess högste befälhavare bär han en stor del av ansvaret för den blodiga etniska utrensningen av den polska befolkningen som utspelade sig i Volynien och Galizien under 1943-1944.

\section{Avrättning av en grupp polska professorer i Lviv: gåtor och kontroverser kring ett krigstidsmord}

I kedjereaktionen av orsak och verkan, med ständigt skiftande konstellationer av tysk, sovjetisk, judisk och ukrainsk makt och maktlöshet, fick den polska komponenten en speciell roll. Efter att de intagit Lviv riktade nazisterna sin utrotningspolitik mot stadens judiska befolkning, och efter utropandet av den ukrainska staten slog de hårt mot ukrainska nationalister. Bland den befolkning av polsk nationalitet som befann sig i Lviv blev den akademiska intelligentian det första offret för nazisternas våldsdåd. Inom polsk minneskultur där stor uppmärksamhet riktas mot den nationella intelligentians insatser (se Smoczyński \& Zarycki, 2017), kom ett angrepp på just denna grupp av polska invånare att få en särställning. En bidragande orsak till detta uppmärksammade dåd har varit de många obesvarade frågor som har skapat en perfekt grogrund för rykten och spekulationer. ${ }^{9}$

\footnotetext{
${ }^{9}$ Till exempel har ingen skriftlig arresteringsorder eller order om avrättningen någonsin hittats (Bolyanovs'kyi, 2011, s. 23). Också har inga förövare dömts eller fängslats för just detta brott. Fallet hördes vid Internationella domstolen i Nürnberg 1946 och öppnades sedan igen i Tyskland och Polen, men det blev praktiskt taget omöjligt att döma förövarna (Albert, 1989, s. 130-31; Bolyanovs'kyi, 2011, s. 63; Schenk, 2011, s. 9-18, 307-72; Hnatiuk, 2015, s. 50).
} 


\section{ELEONORA NARVSELIUS}

Det har dock fastställts bortom allt tvivel att ett Einsatzkommando under ledning av SS-Brigadeführer Eberhard Schöngarth under natten mellan 3 och 4 juli 1941 avrättade en grupp framstående akademiker och deras anhöriga på Wuleckie kullar (Wolka, Wzgórza Wuleckie), praktiskt taget i stadens centrum. Kropparna begravdes på platsen, och hela händelsen observerades av skräckslagna boende i närbelägna hus. Det ofta citerade antalet offer är 45. Bland de avrättade var fem kvinnor. Bland männen fanns 23 professorer, många av dem internationellt kända akademiker anställda vid Ivan Franko-universitetet (före 1940 kallat Jan Kazimierz-universitetet), medicinska institutet, polytekniska institutet, veterinärinstitutet och stadssjukhuset. Professorer i medicin och läkare var den största gruppen, följt av forskare från det polytekniska institutet. Bland offren fanns också en präst, en teologie doktor (Albert, 1989; Bonusiak, 1989; Bolyanovs'kyi, 2011; Krętosz, 2011; Schenk, 2011). ${ }^{10}$

Avrättningen bör sättas i samband med tidigare omfattande nazistiska aktioner riktade mot den polska intelligentian, nämligen Intelligenzaktion som började omedelbart efter Polens militära nederlag och AB Aktion som genomfördes under 1940. Inom ramen för den så kallade Sonderaktion Krakau i november 1939 arresterades 183 anställda vid Jagiellonska universitetet och transporterades till Sachsenhausen. Till skillnad från i Kraków riktades repressalierna i Lviv mot en betydligt mindre grupp akademiker under de första dagarna av den nazistiska ockupationen. Frågan om varför just dessa individer valdes ut för massakern är särskilt intressant och måste besvaras både ur historieforskningens perspektiv och i åminnelsesammanhang.

Det har tagits fram flera möjliga förklaringar som ger en ledtråd till de komplexa motiv och intressen som låg bakom massakern. Ett avgörande skäl för att välja ut denna lilla grupp tycks vara dess påstådda samröre med myndigheterna under den korta sovjetiska perioden. Polens tidigare premiärminister, professor Kazimierz Bartel, liksom flera andra akademiker från Lviv som besökte Moskva strax före den tyska ockupationen, kunde ha utgjort givna mål. Emellertid arresterades endast åtta av delegationens arton medlemmar, trots att tyskarna visste namnen på dem alla. Avrättningarnas selektivitet kan möjligen förklaras med att nazisterna förlitade sig på föråldrade listor, och med att de även i detta fall tillämpade en taktik av slumpmässig terror. Ekonomiska motiv kunde också ha spelat en roll vid gripandet av flera professorer, vars bostäder och värdefulla ägodelar anslogs till nazistanhängare omedelbart efter deras död.

Även om detta brott alltså kunde ha utlösts av flera motiv förefaller det som om en kombination av elitstatus och polsk nationalitet utgjorde ett tillräckligt skäl för utrotning i nazisternas ögon. Att majoriteten av de avrättade på Wuleckie kullar var läkare och vetenskapsmän, ett inflytelserikt och särskilt respekterat skikt i

\footnotetext{
${ }^{10} \mathrm{Om}$ förluster bland Lwówakademin i sviterna efter sovjetiska och nazistiska repressioner se vidare bl.a. Skarzyński, 1995, s. 137-77; Krętosz, 2011, s. 13-14; Redzik, Duda \& Mudry, 2017, s. $984-89,1032-52$.
} 
det polska samhället, förstärker denna slutsats. Även om gruppen var ganska homogen med avseende på etnicitet eftersom de flesta universitetsprofessorer före den tyska ockupationen av Lviv var etniska polacker, inkluderade den dock två judar (dr Stanisław Ruff och hans son), en professor med ukrainska rötter (Adam Sołowij) och en av österrikiskt ursprung (Franciszek Gröer, frisläppt men tillfångatagen på nytt år 1942). Detta tyder snarare på att offrens "ras» var mindre viktiga i detta sammanhang än deras sociala status.

Detta betyder dock inte alls att etnicitet var en faktor av mindre betydelse $i$ det nazistockuperade Lviv. Tvärtom, i otaliga sammanhang blev detta en fråga om liv eller död. Ett ögonvittne beskrev den allmänna avtrubbningen och likgiltigheten gentemot andras öde, där de enda undantagen utgjordes av beprövade personliga relationer och tillgivenhet:

Varje grupp kände smärtan hos dem som var nära, men intresserade sig inte för förödmjukelse eller förtryck av medlemmar av andra grupper. Ukrainarnas öde spelade ingen roll för polackerna eller judarna, och ukrainarna i sin tur var inte intresserade av deras. Individer från olika grupper kontaktade [varandra] endast på grund av långa personliga vänskapsrelationer eller familjeförbindelser. (Pankivskyj, 1965, s. 62-63)

Den tyska regimens brutalitet underblåste lokala etniska konflikter, särskilt den gamla ukrainsk-polska rivalitet som hade förvärrats till följd av den första sovjetiska ockupationen. Den polsk-ukrainska konflikten eskalerade i takt med genomförandet av den "slutliga lösningen" gentemot judarna åren 1942-1943 och kulminerade i omfattande interetniskt våld i Volynien och Galizien. Även om städerna inte påverkades av dessa massakrer i samma utsträckning som landsbygden, blev etniskt motiverade övergrepp en del av den dagliga verkligheten i det nazistockuperade Lviv. Akademin hade förvandlats till en arena för bitter nationell och politisk-ideologisk strid långt före den tyska ockupationen, men naziregimens oöverträffade våld och manipulationer gjöt olja på elden. Genast började spekulationer om att mordet på de polska professorerna inte hade kunnat ske utan ukrainarnas inblandning. Det talades om att OUN:s anhängare i Kraków tidigare hade hjälpt tyskarna att sammanställa proskriptionslistor med namn på "särskilt intressanta» polska akademiker i Lviv. ${ }^{11}$ Dessutom spreds det ett rykte om att ukrainare hade deltagit i själva avrättningen. Med tanke på att Nachtigall-bataljonen befann sig i Lviv under de första dagarna i juli, drog också flera polska historiker slutsatsen att förbandet delade ansvaret för mordet på professorerna. Tadeusz Piotrowskis argument är ganska typiskt:

(...) it is beyond dispute that thousands of Jews and Poles lost their lives in Lwów in those first days of July, that most of the professors died (...) on July 4, 1941, and that Nachtigall was not withdrawn from that city until July 7. Those who deny Nachtigall's participation in these atrocities must tell us what exactly the regiment did there during that time. In any case, since no one has ever stated that the Ukrainian, pro-Nazi

${ }^{11}$ Detta rykte var sanningsenligt, se vidare: Albert, 1989, s. 115; Bonusiak, 1989, s. 72-85; Schenk, 2011 , s. 174 . 


\section{2 | ELEONORA NARVSELIUS}

Nachtigall opposed these atrocities or in any way tried to prevent them, its members are guilty at least of the sin of omission. (Piotrowski, 1998, s. 210-211) ${ }^{12}$

Eftersom den gamla konflikten mellan de galiziska polackerna och ukrainarna underblåstes i det nazistockuperade Lviv, blev inblandningen av ukrainska medlöpare från Nachtigall gradvis etablerad i efterkrigstidens polska och sovjetiska ${ }^{13}$ historieskrivning som en trovärdig förklaring av mordet på de polska professorerna.

Flera intressanta detaljer bör dock pekas ut i sammanhanget, vilka sätter fokus på mellanmänskliga relationer och personliga kontakter samt nyanserar berättelsen om professorsmordet. Dessa detaljer behöver naturligtvis tolkas i ett vidare sammanhang, men de tenderar att ifrågasätta berättelsen om hämndlystna ukrainare som avsiktligt gjorde sig till redskap i detta nazistiska brott.

I Roman Sjukhevytjs museum i Bilohorsitja (en förort till Lviv) kan man se ett intressant dokument med information om tentamina som Sjukhevytj avlagt vid Lwóws polytekniska universitet under läsåret 1926/1927. Bland de examinerande lärarna återfinns professorerna Kazimierz Bartel och Antoni Łomnicki. Roman Sjukhevytj, befälhavaren för det ukrainska förband som utpekades som medansvariga i professorsmordet, var alltså personligen bekant med åtminstone två av de avrättade akademikerna. De var hans universitetslärare och uppskattade honom tydligen som en flitig student, vilket framgår av de betyg som de gav honom: mycket väl godkänt (Bartel) och väl godkänt (Łomnicki). Kunde Sjukhevytj på ett rent mänskligt plan hysa agg mot sina mentorer av vilka han dessutom bodde granne med flera (Tjaikivskyi, 2019, s. 235), och medvetet skicka sina mannar att delta i mordet på dem? Denna fråga förblir retorisk men likväl tankeväckande. Ytterligare en professor som examinerade Sjukhevytj, och vars namn också finns i dokumentet, var den världsberömde matematikern Stefan Banach. Till skillnad från Bartel och Łomnicki blev han inte gripen i början av juli 1941. Som medlem av UkrSSR:s vetenskapsakademi under de första sovjeterna och som en möjlig "sovjetkollaboratör» borde han också ha mött döden på Wuleckie kullar. Han stannade dock kvar i staden och överlevde under svåra omständigheter, nämligen som lössmatare i professor Rudolf Weigls berömda bakteriologiska laboratorium.

Ytterligare en tankeväckande detalj hittar man i Kost Pankivskyjs redan citerade memoarer. Denne var en ukrainsk advokat som under nazistockupationen var ordförande i Nationella rådet (Natsionalna rada), en civil ukrainsk organisation som under tysk översyn sysslade med välgörenhet, skolväsende, kulturliv och hälsa i Galiziendistriktet. Pankivskyj nämner samarbete mellan olika nationella grupper i syfte att förbättra den civila befolkningens situation. Maria Bartel, hustrun till den mördade förre premiärministern, professor Kazimierz Bartel, blev Pankivskyjs viceordförande

\footnotetext{
${ }^{12}$ Denna version avvisas dock i Schenk, 2011, s. 9-18; 307-72, 347 och Motyka, 2015, s. 95-96.

${ }^{13}$ Främst var det tack vare en sovjetisk propagandist och författare, Aleksandr Beliaev (Beviaev, 1978, s. 29 ff.).
} 
i den kommitté som skötte om arbete med fångar (Pankivskyj, 1965, s. 76). Trodde hon inte på ryktena om att ukrainare hade deltagit $\mathrm{i}$ avrättningen av kollegor till hennes man (Bartel mördades något senare och inte på Wuleckie kullar), eller valde hon ändå att samarbeta med ukrainska aktivister för den gemensamma sakens skull? Dessa detaljer säger verkligen något viktigt om omständigheterna i krigstidens multietniska Lviv, där personliga levnadsbanor, intressen och lojaliteter korsades och ändrades på sätt som var ytterst svåra att förutsäga.

\section{Åminnelse av de mördade professorerna i Polen före $1989^{14}$}

Omedelbart efter återtagandet av Lviv i juli 1944 bekräftade de sovjetiska myndigheterna information från den polska exilregeringen i London om professorernas död. Därefter, och fram till början av 1990-talet, gjordes flera försök att hedra offren på båda sidor av den polsk-sovjetiska gränsen. Dessa initiativ utvecklades dock enligt olika scenarier. Den viktigaste orsaken var politiska och geopolitiska uppdelningar i kalla krigets spår och på grund av sovjetstatens ideologiska diktat, men situationen cementerades av mer subtila konflikter.

Strax efter andra världskriget organiserade sovjetiska och polska myndigheter omfattande "repatrieringar» och befolkningsutbyten över den polsk-sovjetiska gränsen, vilket utplånade den återstående polska akademikermiljön i Lviv. Arvtagarna till Lwówakademin var visserligen välkomna i Kraków, men det är viktigt att notera att många skickades till de tidigare tyska territorier som Polen tilldelades år 1945, främst Breslau/Wrocław, för att där inrätta högre utbildning och förstärka den polska identiteten. Det låg inte i de kommunistiska myndigheternas intresse, varken i Polen eller i det sovjetiska Ukraina, att uppmuntra Lwówakademikernas bevarande av en särskild identitet eller deras regelbundna kontakter med de förlorade polska gränsområdena i öst. I Lviv blev samtidigt allt som rörde polackers historiska närvaro och kulturella förtjänster alltmer känsligt, då sovjetiseringen i ukrainsk stil återupptogs efter kriget.

Som en följd av detta förflyttades minnet av de mördade polska akademikernas höga status och martyrskap västerut, främst till de "återvunna områdena", där det i första hand förvaltades av universitetseliten som gradvis förstärkte sina positioner gentemot myndigheterna. Wrocław och Kraków positionerade sig från början som naturliga arvtagare till Lwówakademins traditioner och till de avrättade professorerna. Särskilt i Wrocław, vars befolkning under efterkrigstiden inkluderade mellan 5 och 9\% som fördrivits från Lviv (Goćkowski \& Jałowiecki, 2009, s. 67-96; Kulak, 1997, s. 278 ff.), förankrades minnet av professorerna inte bara i de akademiska kretsarna utan också i den bredare kulturella kontexten. Däremot var utvecklingen annorlunda på andra sidan av Polens reviderade östra gräns, i det ukrainsk-sovjetiska

\footnotetext{
${ }^{14}$ Detta och följande kapitel bygger på material som redovisats utifrån ett annorlunda teoretiskt perspektiv i Narvselius \& Pietraszewski, 2020.
} 


\section{4 | ELEONORA NARVSELIUS}

Lviv. Berättelsen om professorerna fragmenterades, och de olika delarna kom att ingå i flera historiska narrativ. De västukrainska akademiska kretsarna var medvetna om Lwówakademins framgångar, men uppmuntrades inte att upprätthålla ickesovjetiska traditioner och erkänna kontinuitet med mellankrigstidens polska vetenskap. Dock inkorporerades mordet på Wuleckie kullar i berättelsen om det stora fosterländska kriget: de avrättade professorerna kunde presenteras som både sovjetiska offer för, och kämpar mot, "tysk-fascism».

I det socialistiska Polen blev berättelsen om Lwówprofessorerna en del av det traditionella narrativet om den polska nationens martyrdöd och återuppståndelse. I huvudsak pendlade berättelsen mellan två huvudlinjer. Å ena sidan fördömde man nazismen och hedrade alla mördade polska intellektuella $\mathrm{i}$ en politiskt accepterad formel. Akademiker och intelligentia markerades därmed som en speciell kategori av nazisternas offer. Denna berättelse var bekväm för de polska kommunistiska myndigheterna, då den kringgick den utmaning som omnämnandet av Lviv och de förlorade polska länderna i öst (de så kallade kresy) kunde innebära i den rådande politiska situationen. Å andra sidan blev den alternativa berättelsen om just Lwówprofessorernas martyrskap, samt ständiga påminnelser om deras speciella betydelse för Polens annekterade västra länder, mer uttalade mot slutet av den socialistiska perioden.

Turerna kring det monument över Lwówprofessorerna som byggdes i Wrocław illustrerar hur de två olikt vinklade berättelserna samexisterade och konkurrerade med varandra. Efter andra världskriget åsidosattes det tyska akademiska arvet medvetet, samtidigt som de nya polska högskolorna i de annekterade västliga territorierna förkunnade sin institutionella härstamning från Lwówakademin, något som gav staden en starkt emotionell och symbolisk laddning i polska akademiska kretsar. Ett monument över Lwówprofessorerna hade diskuterats i Wrocław ända sedan 1949, men ett förslag lades fram först år 1956 i samband med 15-årsdagen av mordet. Detta initiativ blockerades dock, dels av brist på finansiering och dels av frånvaron av stöd från de polska myndigheterna. Inom universitetet fortsatte man dock att kämpa för saken och organiserade en insamling. Ett minnesmärke, officiellt benämnt "monument över polska forskare, offer för hitlerism», avtäcktes slutligen 3 september 1964 på Wrocławs polytekniska universitetscampus. När lokala tidningar tillkännagav den planerade invigningen tillämpade de den politiskt korrekta formuleringen "martyrskap av alla [kursivering tillagd] polska vetenskapsmän mördade av den barbariska fascismen under andra världskriget» (Mierzecki, 2007, s. 1-2). Under invigningen betonades sekulär heroism, då den offentliga ceremonin inbegrep en militär vakt, militär salut och en marsch av Wrocławakademiker runt det nya monumentet.

Utformningen av minnesmärket var ganska abstrakt. Dess centrala del bestod av stiliserade mänskliga figurer, en av dem fallande och den andra stående, kulregnet till trots (fig. 1). I sitt officiella invigningstal använde sig professor Stanisław Kulczyński, före detta rektor vid Jan Kazimierz-universitetet, av den politiskt godkända retoriken om alla polska vetenskapsmäns martyrskap. Icke desto mindre nämnde 
han också en speciell "vision av den scen som ägde rum den 4 juli 1941, under dödsmuren i sandgropen i Wólka i Lwów» (ibid.). Hans tal sände en signal om att Wrocławs akademiker var fast beslutna att följa sin egen berättelselinje trots politiska påtryckningar.

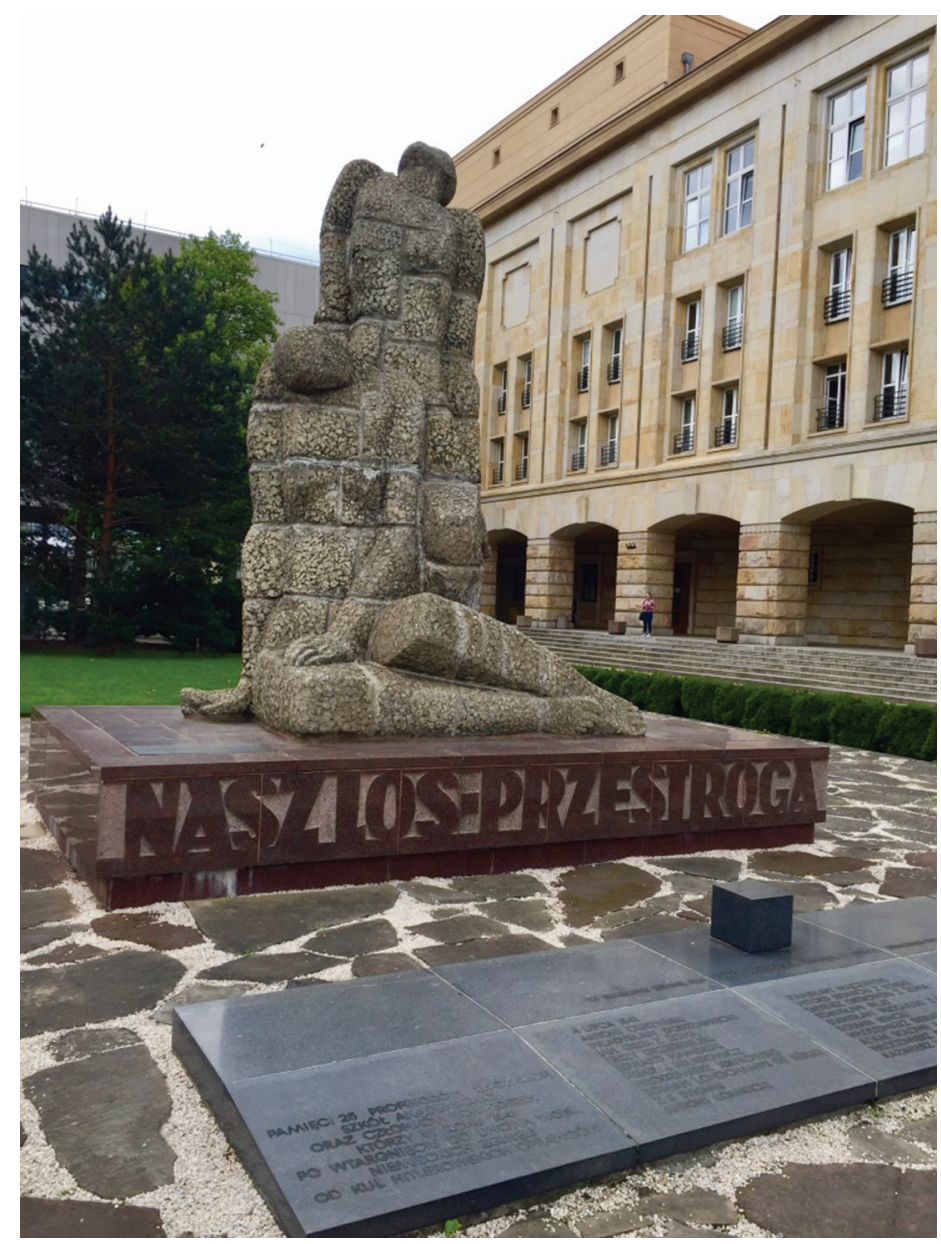

Fig. 1. Monument över de avrättade professorerna i Wroclaw, av Borys Michałowski. Inskriptionen lyder: „Vårt öde varnar». Författarens bild.

År 1966, kort efter invigningen av monumentet i Wrockaw, hedrades professorerna i Kraków. En minnestavla som placerades i franciskankyrkan avslöjade för första gången deras namn i en offentlig lokal. År 1981, kort efter grundandet av Solidaritetsrörelsen, kompletterades också Wrocławmonumentet med en minnestavla med offrens namn. I stället för att vara tillägnat alla polska vetenskapsmän som fallit under andra världskriget, blev detta en plats som uttryckligen dedicerats åt dem som dödades i Lviv. Denna gång leddes avtäckningsceremonin inte av politiker 


\section{6 | ELEONORA NARVSELIUS}

eller akademiska funktionärer utan av änkan efter en av professorerna, dr Maria Witkiewicz. Från att ha varit en arena för konfrontation mellan universitetseliterna som försvarade sitt institutionella arv med rötterna i Lwów, och myndigheterna som insisterade på det nationella narrativet, blev monumentet gradvis en plats för sorg, kontemplation och bön.

\section{Misslyckade försök att högtidlighålla professorernas mord i sovjetiska Lviv}

Minnet av professorsmordet tog en annan inriktning i efterkrigstidens Ukraina. Under hela sovjetperioden betraktades professorsmordet i Lviv som en lokal episod utan större betydelse för sovjetisk-ukrainsk historia eller identitet. År 1946 omdöptes emellertid Abrachamowicz-gatan intill Wuleckie kullar efter den mördade professor Tadeusz Boy-Żeleński, som var medlem i sovjetförfattarnas förening. Det fanns planer på att resa ett monument på mordplatsen för att uppmärksamma 15-årsdagen av brottet, år 1956, men dessa lades på is på grund av den spända politiska situationen efter Stalins död. Som nämnts ovan, misslyckades även Wrocławakademikernas planer på ett motsvarande minnesmärke vid ungefär samma tid.

Medan planen att hedra professorerna med ett monument slutligen genomfördes i Wrocław under 1960-talet, förflöt detta decennium i Lviv utan något liknande initiativ. Själva den historiska händelsen fick emellertid en del uppmärksamhet. I det förändrade politiska klimatet inledde sovjetiska myndigheter en massiv kampanj mot den "ukrainska borgerliga nationalismen». För att diskreditera den ukrainska underjordiska motståndsrörelsen återupplivades historien om de ukrainska nationalisternas samröre med nazisterna. Även om Nachtigall-bataljonen inte ålades ansvar för professorsmordet direkt efter kriget, började sovjetisk propaganda popularisera just denna berättelse under 1960-talet. Det ryktades att det nya sovjetiska monumentet över de avrättade akademikerna skulle innehålla inskriptionen »Till de vetenskapsmän som skjutits av hitleriterna och de ukrainska borgerliga nationalisterna» (Hanitkevych, 2011). Hur detta fantommonument som upprepade gånger diskuterades av de lokala myndigheterna nästan var färdigt, men sedan nedmonterades över en natt, är en märklig historia.

De få bilder som existerar av det i stort sett avslutade projektet visar att Lvivskulptören Emmanuil Mysko skapade sitt verk i konceptuell resonans med Wrocławmonumentet. Båda monumenten var antropomorfa och stiliserade, även om Mysko, som var berömd för sina skulpturporträtt, betonade ansiktsdragen på flera av figurerna. Just denna detalj kunde ha fått förödande konsekvenser. Det ryktades att monumentet monterades ned år 1976 (enligt en annan version år 1980) efter en angivelse som påstod att en av figurerna liknade en Lvivdissident. Enligt en annan version hände detta på grund av att någon myndighetsperson ogillade att monumentet porträtterade den »opålitlige» Kazimierz Bartel som fram till utbrottet av andra världskriget var det »borgerliga» Polens premiärminister. 
Det förefaller emellertid mera sannolikt att det kostsamma monumentet, som kunde tjäna till att diskreditera den nationalistiska rörelsen i västra Ukraina, hastigt nedmonterades inte på grund av en banal angivelse, utan snarare på grund av ett ogynnsamt sammanträffande av politiska omständigheter, precis som under 1950talet. De sovjetisk-polska relationerna blev spända efter de upplopp som ägde rum år 1976 på grund av en chockhöjning av livsmedelspriserna i Polen och Solidaritetsrörelsens efterföljande tillväxt. Ytterligare en anledning till nedtagandet av Myskos monument kan ha varit svårigheten att placera in professorsmordet i den officiella kult av det stora fosterländska kriget som hade utvecklats i Sovjetunionen sedan 1964. Ett brev från chefen för Lvivs regionala kulturavdelning, Jaroslav Vitosjynskyj, daterat 8 juli 1968, antyder att lokala myndigheter initierade diskussioner om monumentet främst på grund av påtryckningar från polska partidignitärer. Att ickenamngivna polska personer av rang gick till själva Sovjetunionens kulturminister Jekaterina Furtseva i detta ärende kan ses som ett bevis på att högtidlighållandet av professorsmorden i Lviv var av särskild betydelse i den polska kontexten. Brevet ger dock också intryck av att ansvariga tjänstemän i Lviv hade svårigheter med att formulera en konsekvent och politiskt korrekt motivering för detta minnesprojekt utifrån det sovjet-ukrainska perspektivet. ${ }^{15}$

Enligt det stora fosterländska krigets framväxande kanon skulle minnesmärken i första hand gälla större grupper, särskilt hjältemodiga soldater och en ospecificerad "fredlig befolkning», och därför stod det inte klart hur man kunde måla in en liten grupp polska akademiker från de sovjetannekterade territorierna i bilden. I stället restes, på den våg av monumentalisering som ägde rum i sovjetiska Ukraina mellan 1966 och 1980, ett annat monument intill Lvivs polytekniska instituts huvudbyggnad (fig. 2). Monumentet invigdes år 1976 för att, som det då stod skrivet på dess sockel, hedra "personal och studenter vid polytekniska institutet som föll i kampen mot fascismen under det stora fosterländska kriget». Något tidigare hade en skulptur uppsatts vid Lvivs medicinska institut för att uppmärksamma sovjetiska läkares kollektiva hjältemod. Även om de flesta som avrättades på Wuleckie kullar var välkända polska läkare, förbigicks detta faktum och i stället markerades den självuppoffrande kamp som förts av alla sovjetiska läkare under kriget. Under hela sovjetperioden hedrade alltså Lviv namnlösa heroiska vetenskapsmän och intelligentia i enlighet med den officiella formel som övergavs i Polen efter 1981.

Även om det är frestande att förklara det uteblivna minnesmärket över professorerna med enbart de centrala kommunistiska makternas ideologiska direktiv, bör man inte glömma bort den lokala kontexten i vilken polskhet var ett fortsatt känsligt och kontroversiellt ämne. Med all sannolikhet glödde ett outtalat motstånd mot etablering av det polska martyrdomsnarrativet i efterkrigets ukrainska Lviv, i synnerhet mot att de ukrainska nationalistiska krafterna belastades med medansvar

${ }^{15}$ DALO (Statsarkiv av Lvivoblast), Proekt pam'iatnyka, fond P-1338, op. 1, od. zberihannia 1068, ark. 22-23. 


\section{ELEONORA NARVSELIUS}

för professorernas förintelse. En hemlig rapport adresserad till det ukrainska kommunistpartiets högsta dignitär Volodymyr Sjtjerbytskyj i slutet av år 1980 nämner drygt tjugotusen före detta anhängare till OUN (byvsjyie ounovtsy) bosatta i Lviv oblast som en huvudkälla av "ohälsosamt, och ibland fientligt prat». ${ }^{16}$ Som Rothberg poängterade, "the emergence of memories into the public often takes place through triggers that may at first seem irrelevant or even unseemly» (Rothberg, 2009, s. 17). Av allt att döma fortsatte det lokala "mångdimensionella minnet» att utvecklas i sin egen takt under den sovjetiska perioden, och man kan ana att den fortsatta oviljan att hedra polska offer för nazistockupationen var väl förankrad på lokal nivå.

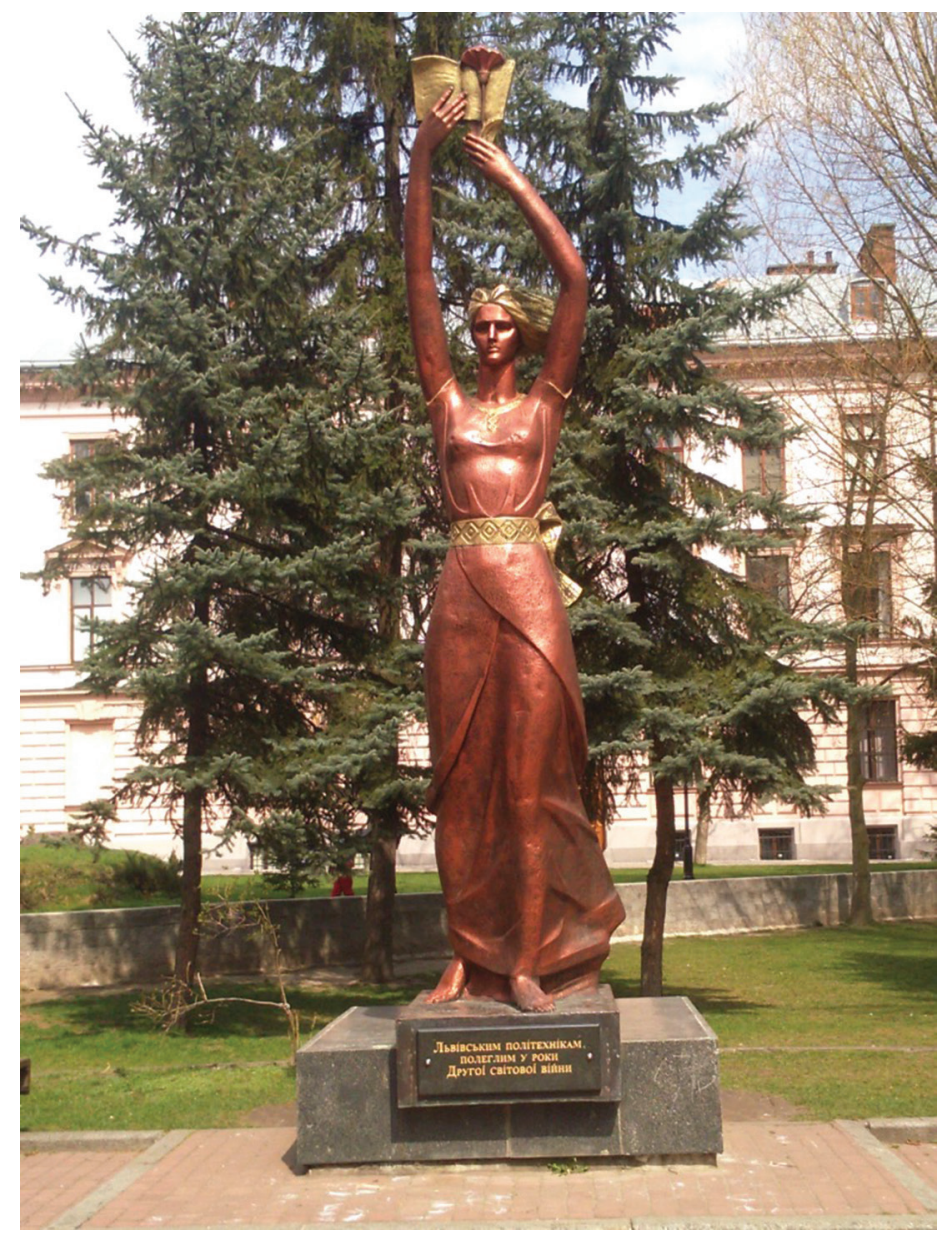

Fig. 2. Det restaurerade sovjetiska monumentet med en ändrad dedikation som numera lyder: "Till alla de från Lvivs polytekniska institut som föll under andra världskriget». Författarens bild.

${ }^{16}$ DALO (Statsarkiv av Lvivoblast), Pervomu sekretariu TsK Kompartii Ukrainy tovarishchu Shcherbitskomu Vladimiru Vasil'ievichu. O politicheskoi obstanovke vo L'vovskoi oblasti, fond P-3, op. 4, sprava 85, od. zberihannia 364, ark. 33. 


\section{"Ett monument utan inskription": minnesmärket över Lwówprofessorerna efter det sovjetiska systemets fall}

Med det socialistiska blockets kollaps började idén om att hedra de avrättade professorerna med ett monument i Lviv cirkulera på nytt. De polsk-ukrainska politiska relationerna var goda och intresset för galizisk mångkultur ökade kraftigt under 1990-talet. Därför blev det nu möjligt även för utbildningsinstitutioner i Lviv att återknyta till sin försovjetiska historia och placera sig som förvaltare av professorernas minne. Tidigare kontakter och vänskapliga relationer, i synnerhet mellan Lvivs polytekniska instituts rektor, Jurij Rudavskyi, och hans motsvarighet i Wrocław, Andrzej Wiszniewski, spelade en viktig roll i denna process. Ändå lades planerna för ett monument på Wuleckie kullar på is även denna gång. Detta berodde delvis på ekonomiska svårigheter, men var också en följd av det förändrade politiska klimatet, där retoriken om nationell stolthet och nationellt lidande började bli alltmer högljudd både på den polska och den ukrainska sidan. Trots detta organiserades år 1994 det första offentliga arrangemang som uppmärksammade Lvivs och Wrocławs gemensamma akademiska arv. En utställning med den i sammanhanget sensationella titeln Förfäder och fäder. Insatser av polska medlemmar av arkitekturfakulteten vid Lvivs polytekniska universitet visades i båda städerna. Ett år senare uppsattes en minnestavla på den byggnad där geodesiforskaren professor Kaspar Weigel, ett av offren från Wuleckie kullar, bodde till sin död.

I Ukraina banade dessa initiativ vägen för ett offentligt erkännande av det polska akademiska arvet, i synnerhet vid Lvivs polytekniska universitet, där en korridor i huvudbyggnaden numera uppvisar porträtt av alla dess rektorer, av vilka de flesta var polacker. Universitetets museum innehåller numera flera föremål som hänvisar till de avrättade professorerna - dock som en del av den övergripande berättelsen om universitetens öde under de två totalitära regimerna, med särskilt fokus på sovjetiskt förtryck. Denna logik medförde att porträtt av de avrättade professorerna och OUN(b)-ledarna Stepan Bandera och Roman Sjukhevytj placerades sida vid sida i museets hall. Placeringen av dessa nationalistiska aktivister som dödades av sovjetregimen på 1950-talet bland de akademiska martyrerna kan förklaras med hänvisning till att de båda studerade vid det polytekniska universitetet före kriget och föll offer för repressiva politiska regimer (fig. 3). Enligt samma princip förevisar Ivan Franko-universitetets museum Zygmunt Alberts bok om professorsmordet sida vid sida med publikationer om ukrainska dissidenter från efterkrigstiden. Den permanenta utställningen i Lvivs medicinska akademis museum nämner å andra sidan inte alls att dess framstående medarbetare föll offer för naziregimen. Professorerna Franciszek Gröer, Jan Grek och Antoni Cieszyński nämns i sin egenskap av världsberömda representanter för akademin. Samtidigt fokuserar utställningen på de läkare som var en del av den ukrainska nationella rörelsen. 


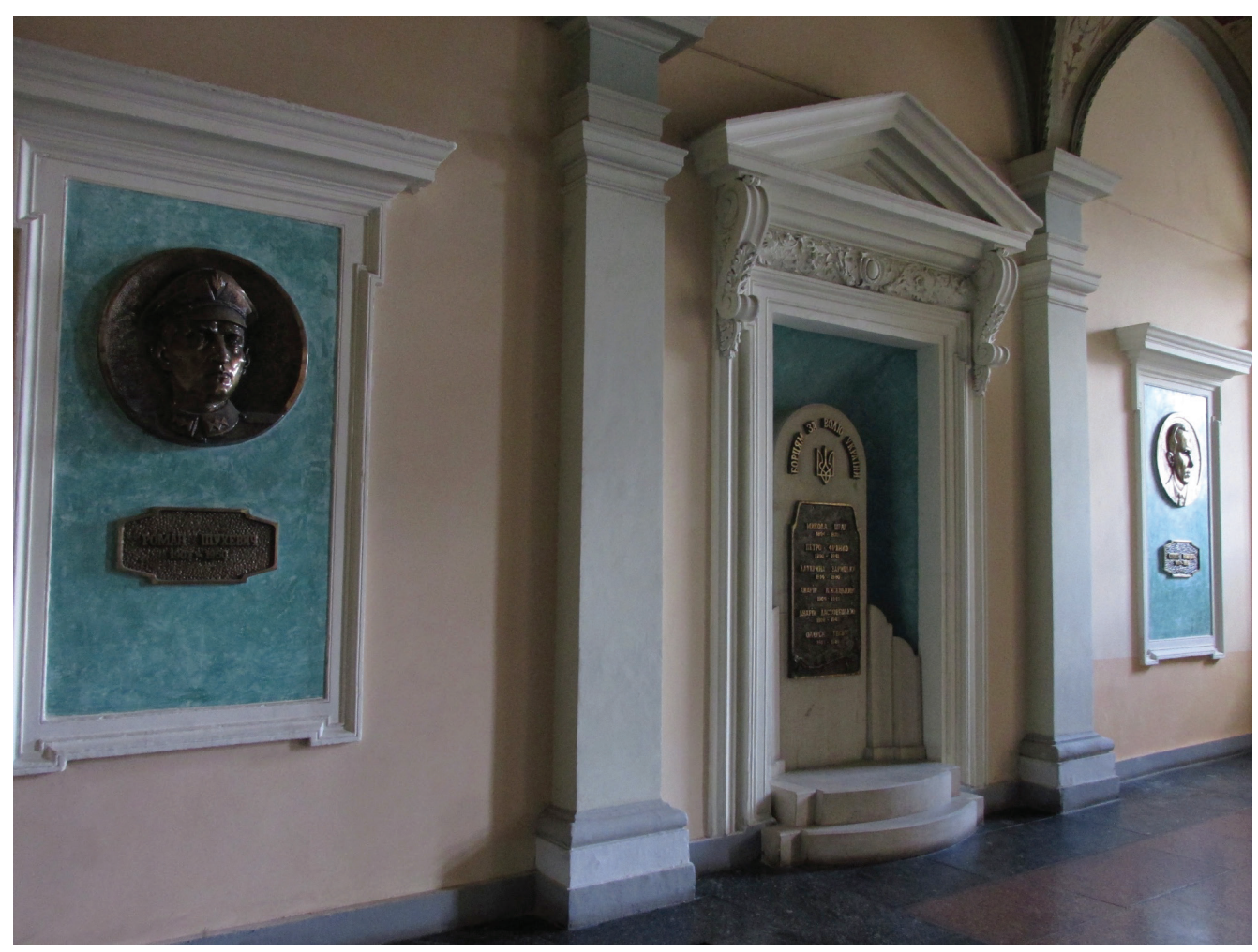

Fig. 3. Roman Sjukhevytjs och Stepan Banderas reliefer i Lvivs polytekniska universitets huvudbyggnad. Författarens bild.

Av olika anledningar förpassades mordet på de polska professorerna i Lviv till utkanten av åminnelsepolitiken efter Ukrainas självständighet år 1991. En förändring skedde dock år 2008, då borgmästarna i Lviv och Wrocław utlyste en designtävling för ett nytt minnesmärke på Wuleckie kullar. Det är intressant att notera att intervjuer med de inblandade tjänstemännen och akademikerna visar att det som var avgörande för initiativets slutliga framgång var personligt engagemang och vänskapliga relationer mellan flera inflytelserika aktörer i de båda städerna, framför allt mellan borgmästarna Sadovyj och Dutkiewicz. Det monument som avtäcktes 3 juli 2011, på 70-årsdagen av professorernas avrättning, blev det andra minnesmärket $\mathrm{i}$ det postsovjetiska Lviv som tillägnades icke-ukrainare. Det första var Förintelsemonumentet. Konceptuellt hänvisar minnesmärket på Wuleckie kullar till Bibeln och betonar det mänskliga livets okränkbarhet. Dess centrala del är en portal med tio stenar symboliserande de tio budorden. Den femte stenen, som representerar budet "Du skall inte döda", står ut från resten av strukturen (fig. 4). Avsikten var alltså att understryka gemensamma religiösa värderingar och på så sätt undvika den kontrovers som lätt skulle kunna uppstå om monumentet hade innehållit ikoniska representationer av polskhet. 


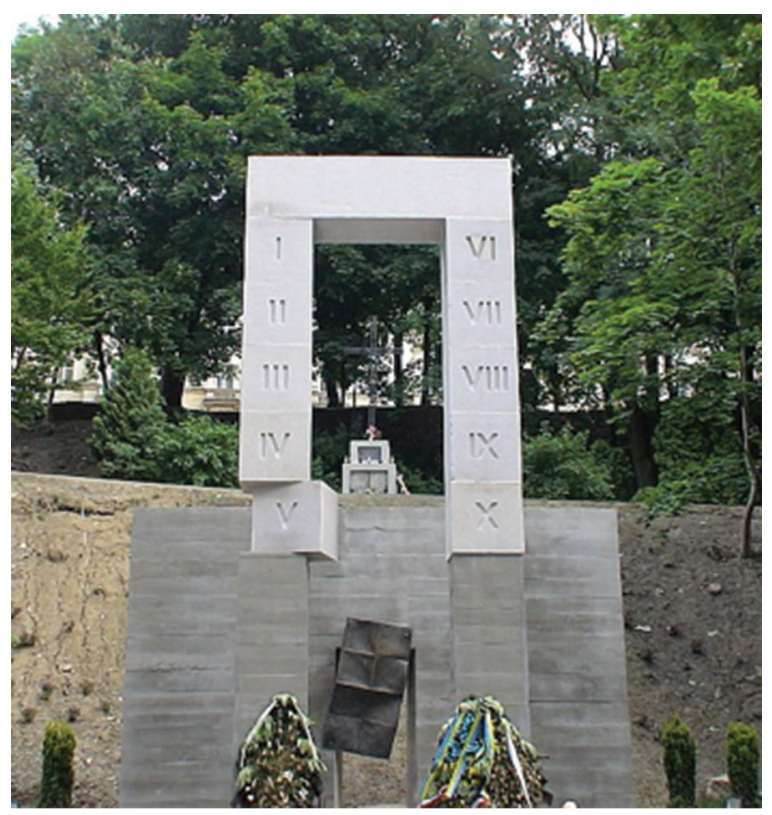

Fig. 4. Det nya professorsmonumentet invigt 2011. I bakgrunden syns ett minnesmärke med kors som installerades under 1990-talet på initiativ av den lokala polska befolkningsgruppen. Författarens bild.

Monumentet har alltså inga spår av nationell symbolism, och inte heller någon text. Det senare gav upphov till kritiska kommentarer i de polska medierna. ${ }^{17} \mathrm{Monu}-$ mentet inkluderar en bronsdetalj som liknar ett uppvikt pappersark, men det är tomt. Det har sagts att den ursprungliga planen innefattade en (aldrig funnen) order att avrätta professorerna som skulle inristas på bronsarket. Andra källor uppgav att ingen sådan inskrift hade planerats. Enligt ännu en kommentator lämnades monumentet utan inskriptioner eftersom de polska och ukrainska parterna inte kunde enas om användningen av adjektivet "polsk». En formulering som godkänts av de lokala myndigheterna i Lviv och Wrocław använde uttrycket "Lvivprofessorerna", men detta avvisades av den statliga polska institutionen Rada Ochrony Pamięci Walk $i$ Męczeństwa (Råd för minnesskydd av kamp och martyrdom) som i stället insisterade på »de polska professorerna». År 2012 uppsattes emellertid en granitsten med dedikation på tre språk till "professorer från Lviv (på polska, professorów Lwowskich) som mördades av nazisterna år 1941» på den väg som leder till monumentet.

Som en följd av dessa kontroverser ifrågasattes det gemensamma minnesinitiativet både av en grupp radikala politiker från Lviv och av den polska sidan. I en artikel som

\footnotetext{
${ }^{17}$ Se t.ex. "Lwowski pomnik polskich profesorów bez napisu,» TVP Info (2011, 3 juli). Hämtat 13 juli 2017 från www.tvp.info/4814195/lwowski-pomnik-polskich-profesorow-bez-napisu.
} 
publicerades kort före den officiella öppningsceremonin hävdade historikern Piotr Łysakowski, ansluten till Polska nationella minnesinstitutet (IPN), att ukrainare deltog i mordet på professorerna (Łysakowski, 2011). Före detta borgmästaren i Lviv, Vasyl Sjpitzer, parerade att de avrättade professorerna i själva verket var sovjetiska kollaboratörer och ukrainofober (Polski vtjeni, 2011).

I stort sett var installationen av ett monument på Wuleckie kullar ett framgångsrikt initiativ, som slutligen uppmärksammade denna viktiga, men av politiska och ideologiska skäl kontroversiella grupp av andra världskrigets offer. Som ett nästa steg i populariseringen av deras minne planerades en specialutställning på Lvivs polytekniska universitetets campus. År 2011 genomfördes emellertid inte detta projekt på grund av allvarliga meningsskiljaktigheter mellan de polska och ukrainska parterna om dess form och innehåll. Efter 2014 lades det på is, med krigföringen i Ukraina som en ursäkt.

Under 2016 sammanföll 75-årsdagen av professorsmorden med en resolution av polska Seim som definierade krigstida massakrer på polacker i Volynien och Galizien som ett folkmord begått av OUN och dess militära styrka UPA. Detta år färgades hyllningsceremonin vid monumentet av en känsla av förbittring. Även om både de ukrainska och de polska delegationerna bestod av höga tjänstemän och ceremonin fick mycket uppmärksamhet i media, var de officiella talen klichéartade och stämningen ganska spänd. Uppenbarligen hade monumentet nu blivit kopplat till den polsk-ukrainska tvisten om det historiska minnet som blivit alltmer polariserad sedan början av 2000-talet. Det är alltjämt viktigt och betydelsefullt för både ukrainska och polska åminnelseaktörer att de mördade professorerna hedras. Inte heller har den grundläggande idén om att "inför vetenskapen, liksom inför Gud, är alla lika» förlorat sin betydelse för polska och ukrainska akademiska eliter. Detta hindrade dock inte att monumentet blev vandaliserat 10 mars 2017. Detta officiellt invigda monument, som enligt skeptikerna endast symboliserar en påtvingad konsensus, förvandlades plötsligt till en ny frontlinje i det polsk-ukrainska kriget om det historiska minnet.

Som det ofta är fallet med minneshändelser, "[i]t is often difficult to tell whether a given act of memory is more likely to produce competition or mutual understanding - sometimes both seem to happen simultaneously» (Rothberg, 2009, s. 11). Meningsskiljaktigheter i frågan om minnet av och minnesmärket över de mördade professorerna visar än en gång att den galiziska mångfalden har sina efterdyningar i form av bestående politisk-kulturella skiljelinjer och konflikter om det förflutna. Samtidigt blir det dock tydligt att det finns möjligheter för olika parter, motsättningarna till trots, att enas kring gemensamma värden, särskilt när processerna bygger på redan existerande goda personliga relationer, vänskaper och lojaliteter. I efterhand måste det dock påpekas att den uppmärksamhet som riktats mot offer från en viss framstående grupp tonar ned komplexiteten hos krigssituationen i Lviv, där flera grupper, av vilka den största var judar, utrotades samtidigt. 


\title{
Om artikkelen
}

\author{
Denna studie möjliggjorts genom generöst bidrag från Erik Philip-Sörensens stif- \\ telse för främjande av genetisk och humanistisk vetenskaplig forskning.
}

\section{Referenser}

Albert, Z. (1989). Kaźn profesorów lwowskich, lipiec 1941. Wrocław: Wydawnictwo Uniwersytetu Wrocławskiego.

Barkan, E., Cole, E. \& Struve, K. (Red.) (2007). Shared history, divided memory: Fews and others in Sovietoccupied Poland, 1939-1941. Leipzig: Leipziger Universitätsverlag.

Bartov, O. \& Weitz, E. D. (Red.) (2013). Shatterzone of empires: Coexistence and violence in the German, Habsburg, Russian, and Ottoman borderlands. Bloomington: Indiana University Press.

Beviaev, V. (1978). Ia obviniaiu! Moskva: Politizdat.

Bialasiewicz, L. (2003). Another Europe: Remembering Habsburg Galicja. Cultural Geographies, 10, 21-44.

Bolyanovs'kyi, A. (2011). Ubyvstvo pol's'kykh uchenykh u L'vovi v lypni 1941 roku: fakty, mify, rozsliduvannia. L'viv: Vydavnytstvo L'vivs'koi politekhniky.

Bonusiak, W. (1989). Kto zabit profesorów lwowskich? Rzeszów: Krajowa Agencja Wydawnicza Rzeszów.

Czaplicka, J. (2002). "L'viv, Lemberg, Leopolis, Lwów, Lvov: A city in the crosscurrents of European culture». I J. Czaplicka (Red.) L'viv: A city in the crosscurrents of culture: Harvard Ukrainian Studies, special issue, vol. 24 (s. 13-47). Cambridge MA: Ukrainian Research Institute, Harvard University.

Goćkowski, J. \& Jałowiecki, B. (2009). Prace nadesłane na konkurs 'Czym jest dla ciebie miasto Wrocław' jako materiał socjologiczny. I J. Wojtaś (Red.), Wrocławskie reminiscencje socjologiczne (s. 67-96). Wrocław: Wydawnictwo DTSK "Silesia".

Hanitkevych,Y. (2011). Tragediia hrupy l'vivs'kykh profesoriv u 1941 rotsi (do 70-ii richnytsi straty vchenykh). I Naukove Tovarystvo im. T. Shevchenka, On-line zhurnal Tovarystva, blog Yaroslava Hanitkevycha, October 10, 2011. Hämtat 5 juni 2019 från ntsh.org/content/ganitkevich-ya-tragediya-grupi-lvivskih-profesorivu-1941-roci-do-70-yi-richnici-strati.

Hann, C. M. (2005). The limits of Galician syncretism: Pluralism, multiculturalism, and the two Catholicisms. I C. M. Hann \& P. R. Magocsi (Red.), Galicia: A multicultured land (s. 210-237), Toronto: University of Toronto Press.

Hann, C. M. \& Magocsi, P. R. (2005). Galicia: A multicultured land. Toronto: University of Toronto Press.

Himka, J. P. (2011). The Lviv pogrom of 1941: The Germans, Ukrainian nationalists, and the carnival crowd. Canadian Slavonic Papers, 53(2-4), 209-243.

Hnatiuk, O. (2015). Vidvaha $i$ strakh. Kyiv: Dukh i litera.

Hryciuk, G. (2000). Polacy we Lwowie 1939-1944: Życie codzienne. Warszawa: Książka i wiedza.

Khakhula, L. (2016). „Rizuny” chy pobratymy? Suchasni pol's'ki dyskursy pro Ukrainu. Lviv: Instytut ukrainoznavstva im. I. Kryp'iakevycha.

Kiebuzinski, K. \& Motyl, A. (Red.) (2017). The great west Ukrainian prison massacre of 1941. A sourcebook. Amsterdam: Amsterdam University Press.

Krętosz, J. (2012). Likwidacja kadry naukowej Lwowa w lipcu 1941 roku. I K. Heska-Kwaśniewicz, A. Ratuszna \& E. Żurawska (Red.), Niezwykła więź Kresów Wschodnich i Zachodnich. Wpływ lwowian na rozwój nauki $i$ kultury na Górnym Ślasku po 1945 roku (s. 13-21). Katowice: Studio Noa.

Kulak, T. (1997). Wrocław. Przewodnik historyczny. Wrocław: Wydawnictwo Dolnośląskie.

Liber, G. (2016). Total wars and the making of modern Ukraine, 1914-1954. Toronto: University of Toronto Press.

Linkiewicz, O. (2018). Lokalność $i$ nacjonalizm: spoleczności wiejskie w Galicji Wschodniej w dwudziestoleciu międzywojennym. Kraków: Towarzystwo Autorów i Wydawców Prac Naukowych Universitas.

Łysakowski, P. (2011, 22 juni). Strzały na Wzgórzach Wuleckiech 22 czerwca 2011. Rzeczpospolita. Hämtat 13 juli 2017 från https://archiwum.rp.pl/artykul/1058546-Strzaly-na-Wzgorzach-Wuleckiech.html

Magocsi, P. R. (2005). Galicia: A European land. I C. M. Hann \& P. R. Magocsi (Red.), Galicia: A multicultured land (s. 3-21) Toronto: University of Toronto Press.

Makarchuk, S. (2007). Zminy v etnosotsial'nii strukturi naselennia L'vova v pershii polovyni XX stolittia. Visnyk L'vivs'koho universytetu. Seriia istorychna. Spetsvypusk (s. 445-355). L'viv: Vydavnytstvo L'vivs'koho universytetu.

Mick, C. (2015). Lemberg, Lwów, L'viv, 1914-1947: violence and ethnicity in a contested city. West Lafayette IN: Purdue University Press. 


\section{ELEONORA NARVSELIUS}

Mierzecki, R. (2007). Budowa wrocławskiego pomnika w latach 1956-1964 ku czci polskich profesorów zamordowanych we Lwowie w 1941 roku, Analecta 16(1-2). Hämtat 18 augusti 2017 från http://www. lwow.home.pl/mierzecki/analecta.html

Motyka, G. (2015). Ukraińska partyzantka 1942-1960. Działalność Organizacji Ukraińskich Nacjonalistów $i$ Ukraińskiej Powstańczej Armii. Warszawa: Oficyna Wydawnicza RYTM.

Müller, E. (2012). 1939/41 - Umsiedlungen der zerstreuten ostdeutschen Volksgruppen in die neu gegründeten Reichsgaue. Hilfskomitee der Galiziendeutschen e.V. 6, 1-4. Hämtat 19 augusti 2019 från https://www. galizien-deutsche.de/hochgeladen/dateien/Umsiedlung-1939-Prof.E.Mueller.pdf

Narvselius, E. (2019). Introduction. Remembering historical diversity in East-Central European borderland cities. Fournal of Soviet and Post-Soviet Politics and Society, 5(2), 1-28.

Narvselius, E. \& Pietraszewski, I. (2020). Academics executed on the Wulecki Hills in L'viv: From a local wartime crime to a translocal memory event. Slavic Review, 79(1), 139-62.

Pankivskyi, K. (1965). Roky nimets'koi okupatsii. New York, Toronto: eget förlag.

Partyliak, I. (2004). Vijs'kova diial'nist'OUN(b) u 1940-1942 rokakh. Kyiv: Instytut istorii Ukrainy NAN Ukrainy.

Piotrowski, T. (1998). Poland's Holocaust: Ethnic strife, collaboration with occupying forces and genocide in the Second Republic, 1918-1947. Jefferson, NC \& London: McFarland.

Pol's'ki vcheni, rozstriliani u L'vovi, spivpratsiuvaly z bol'shevykamy - eks-mer (2011, 4 april). Zaxid. Hämtat 13 juli 2017 från https://zaxid.net/polski_vcheni_rozstrilyani_u_lvovi_spivpratsyuvali_z_bilshovikami_ eksmer_n1126313

Redzik, A. (2017). Uniwersytet w latach 1918-1939. I A. Redzik, R. Duda \& M. Mudry (Red.), Academia Militans. Uniwersytet fana Kazimierza we Lwowie (s. 157-97). Krakow: Wydawnictwo Wysoki Zamek.

Redzik, A., Duda, R. \& Mudry, M. (Red.) (2017). Academia Militans. Uniwersytet Fana Kazimierza we Lwowie. Krakow: Wydawnictwo Wysoki Zamek.

Rothberg, M. (2009). Multidirectional memory: Remembering the Holocaust in the age of decolonization. Stanford: Stanford University Press.

Rudling, P. A. (2019). Rehearsal for Volhynia: Schutzmannschaft Battalion 201 and Hauptmann Roman Shukhevych in occupied Belorussia, 1942. East European Politics and Societies 34(1), 158-93.

Schenk, D. (2011). Noc morderców. Kaźń polskich profesorów we Lwowie i holokaust w Galicji Wschodniej. Kraków: Wysoki Zamek [översättning från tyska originalet, Der Lemberger Professorenmord und der Holocaust in Ostgalizien. Bonn: Dietz, 2007].

Shkandrij, M. (2015). Ukrainian nationalism: Politics, ideology, and literature, 1929-1956. New Haven: Yale University Press.

Skarzyński, T. (1995). Martyrologia, straty wojenne i okupacyjne środowiska Politechniki Lwowskiej (19181945). I Politechnika Lwowska macierz polskich politechnik. Materialy konferencji naukowej. Wrocław, 25-26 wreśnia (s. 137-77). Wrocław: Wydawnictwo Politechniki Wroclawskiej.

Smoczyński, R. \& Zarycki, T. (2017). Totem inteligencki: arystokracja, szlachta i ziemiaństwo w polskiej przestrzeni spotecznej. Warszawa: Wydawnictwo Naukowe "Scholar».

Spickard, P. R. (1989). Mixed blood: Intermarriage and ethnic identity in twentieth-century America. Madison, WI: University of Wisconsin Press.

Szablowski, W. (2016). Sprawiedliwi zdrajcy: sqsiedzi z Wotynia. Kraków: Społeczny Instytut Wydawniczy Znak.

Tjajkivskyj, B. (2019). Shakhivnytsia moho zhyttia. I A. Sova (Red.) Roman Shukherych u hromads'ko-politychnomu zhytti Zakhidnoi Ukrainy 1920-1939 rr. Spohady, dokumenty, svitlyny (s. 232-87). Lviv: Apriori.

Wendland, A. W. (2005). Neighbors as betrayers: Nationalization, remembrance policy, and the urban public sphere in L'viv. I C. M. Hann \& P. R. Magocsi (Red.), Galicia: a multicultured land (s. 239-259), Toronto: University of Toronto Press.

Wnęk, K., Zyblikiewicz, L. \& Callahan, E. (Red.) (2006). Ludność nowoczesnego Lwowa w latach 1857-1938. Krakow: Towarzystwo naukowe Societas Vistulana.

Wnuk, R. (2013). Recent Polish historiography on Polish-Ukrainian relations during World War II and its aftermath. Hämtat 10 augusti 2019 från http://ece.columbia.edu/files/ece/images/ wnuk-1.pdf.

Wolff, L. (2010). The idea of Galicia: history and fantasy in Habsburg political culture. Stanford: Stanford University Press.

Zaitsev, O. (2013). Ukrains'kyi intehral'nyi natsionalizm (1920-ti-1930-ti roky). Narysy intelektual'noi istorii. Kyiv: Krytyka.

Zashkilniak, L. (2008). Ukrains'ko-pol's'ki stosunky XX st. u spil'nii svidomosti ukraintsiv i poliakiv. I Visnyk Lvivs'koho universytetu. Seriia sotsiolohichna, 2 (s. 127-37).

Zavorotna, N. (2020). Scholars in exile. The Ukrainian intellectual world in interwar Czechoslovakia. Toronto: University of Toronto Press. 